\title{
Bergman, Torbjörn, Gabrielle Ilonski, Wolfgang C. Müller, Hrsg. 2019. Coalition Governance in Central Eastern Europe
}

\author{
Oxford: Oxford University Press, 624 S., \$ 115.00, \\ ISBN 9780198844372
}

\section{Petra Stykow}

Published online: 18 June 2020

(C) The Author(s) 2020

This volume gathers and analyzes data on cabinets and coalition politics in ten Central East European (CEE) countries, covering the time span between the early 1990s and 2014. The analytical framework, which guides this research endeavor, is borrowed from the seminal book on "Coalition Governments in Western Europe", edited by Wolfgang C. Müller and Kaare Strøm (OUP 2000) with its configurative accounts of coalition life-cycles in thirteen parliamentary and semipresidential democracies for the period from 1945 to 1998.

Apart from enlarging the extant database by filling a geographical gap in the study of coalition politics, the editors-Wolfgang C. Müller (Vienna), Torbjörn Bergman (Umeå) and Gabriella Ilonszki (Budapest)_pursue ambitious methodological and theoretical goals. As they announce in the introductory chapter, the inclusion of CEE countries is meant to spur causal reasoning about institutional effects on coalition politics by increasing the number of cases and to allow out-of-sample testing of theories that have originally been developed in the context of Western European democracies. In addition, the study aims to investigate CEE-specific explanatory factors, such as the role of communist successor parties, the degree of party system institutionalization, party splits and fusions as well as parties' past defective behavior in coalition governments. Also, assuming ongoing catch-up processes in CEE, signs of institutional learning are sought that result from the intrinsic dynamics of multiparty democracies as well as from inspirational learning from West European parties and their coalition behavior.

The chapters on Bulgaria, the Czech Republic, Estonia, Hungary, Latvia, Lithuania, Poland, Romania, Slovakia, and Slovenia are written by proven, often renowned,

Prof. Dr. P. Stykow $(\bowtie)$

Geschwister-Scholl-Institut für Politikwissenschaft, Ludwig-Maximilians-Universität München,

Oettingenstr. 67, 80538 Munich, Germany

E-Mail: Petra.stykow@1mu.de 
country experts. They all follow the same structure, adopted from the 2000 book on coalition politics in Western Europe. The authors present meticulously accumulated information on all aspects of coalition politics in each country, including the most relevant features of the national party system and the formal rules that condition the coalition game. A series of standardized tables conveniently provide comparable data for all countries. True, it is not always easy to find one's way through the abundance of empirical details, especially in the face of the many party names and the poorly decoded abbreviations used in the tables. All in all, however, the reader gains an extraordinarily well-informed impression of the enormous variance of coalition politics in CEE.

In the concluding chapter, the three editors sketch comparisons between the countries under scrutiny, but their main thrust is on comparing coalition politics in Western Europe (WE), on the one hand, and Central Eastern Europe, on the other hand. In particular, they are impressed with the similarities between the two regions, concerning the types of government, especially by roughly the same shares of minority governments and minimal winning coalitions, as well as by the similar likelihood that the median parties on the left-right dimension participate in cabinets. Further, coalition partners in CEE share the same trend towards coalition agreements as in WE, and they use quite similar coalition governance mechanisms. They also allocate cabinet portfolios largely according to the proportionality norm, thus confirming once more Gamson's law, one of the strongest empirical regularities in social sciences.

As for the differences between WE and CEE, the authors note fewer single-party governments and more oversized coalitions in the second region. Cabinets tend to need more time to be formed, coalition agreements are less detailed, coalition governance is probably less efficient, and politicians are more likely office-seekers than policy-seekers. On average, CEE cabinets survive for considerably shorter periods than in WE. They are terminated a little less often for technical reasons such as regular parliamentary elections. Mostly (and similar to WE), governments fall over conflicts between the coalition partners, followed by intra-party conflicts, but it is remarkable that cabinet termination leads less often to early elections than in WE. This mirrors the regular absence of the "election rule" in coalition agreements, forcing new elections in case the coalition breaks down. Also, the anti-incumbency effect is even stronger in CEE than in WE, so that parties, which participate in government, face highly likely considerable losses in the next election.

To be sure, the authors also point to between-country variation within the region. However, only when scrutinizing the various modes of governance, they explore this variation in a systematic and time-sensitive manner. While not fully corresponding to the overall thesis that the region shows a "stronger tendency to ministerial government than in WE" (p. 523), figure 13.2 (p. 557) is instructive in this regard. It displays a clear trend towards the coalition compromise ("collegial") model in six of the ten countries, starting after the first post-communist decade. By contrast, Lithuania and Latvia seem to move towards ministerial government, while Hungary's and Poland's cabinets are (in the case of Poland: increasingly) dominated by the Prime Minister. 
Overall, however, the editor's main emphasis is on contrasting WE and CEE as "macro-regions". This raises some objections. First, there is a data problem. Even if for Western Europe more recent data are occasionally used, the permanent reference to the 2000 book suggests that the comparison is between two geographical regions, which, however, are averaged over different time spans. Second, there is a problem of case selection. Within the earlier Comparative Parliamentary Democracy program, "Western Europe" comprises countries regardless of their EU membership. In contrast, "Central Eastern Europe" is constructed as "EU-CEE", and this as of 2012 (Croatia became a member state in 2013, but was not included in the study). While there may be plenty of reasons not to include the remaining (electoral) democracies in the European East, the geopolitical criterion is certainly not methodologically sound. The lack of reflection on this issue is astonishing.

Third, the effort to contrast WE and EU-CEE as macro-regions continues the traditional "othering" of Central and Eastern Europe. Yet, this perspective is both outdated and theoretically harmful. True, the question of when and how the postcommunist region will catch up with the West informed much of comparative research in the 1990s and early 2000s. In the meantime, however, it became increasingly clear that Eastern Europe got tremendously heterogeneous, so that simply averaging individual country data might obscure more than it reveals. Besides, also the West is changing in a way and direction that is not well understood so far. Some scholars on parties and party systems, for example, suggest CEE being less of a democratization laggard than a precursor to turbulences, which are about to affect older democracies as well-an insight the editors also refer to (p. 523), but do not substantiate.

In fact, the more important potential of the present research project probably consists in taking a closer look at the presumed regional factors, which may influence coalition politics. In this regard, my main point of critique concerns the focus and the rigidity of the analytical framework. On the one hand, this framework demands presenting potential explanatory factors, i.e., political institutions and the features of national party systems in EU-CEE, as merely background conditions, which are compiled in the second chapter of the book as well as in the first parts of each country chapter. This way of organizing the material turns the country chapters into some kind of data suppliers for further statistical research instead of encouraging causal reasoning, or meaningful process tracing, for that matter.

On the other hand, the research framework which had been developed in the late 1990s necessarily centers on assumptions about coalition politics in the old European democracies. As a result, contextualization is doomed to remain superficial, and the announced new indicators for interpreting coalition politics in CEE are not discussed in a systematic manner. For example, the framework has a static grip, which does not fit the observation of two relatively clearly distinguishable periods in the evolution of coalition politics, made by most country experts. These periods are separated by major reconfigurations of the party system and/or levels of party system institutionalization, which often (but not always) mirror the end of the postcommunist "regime divide". While some case studies stress coalition politics as a factor of party-building on its own, especially in the earlier period, neither the case studies nor the concluding chapter deal with this nexus systematically. 
Communist successor parties are another issue, which has not been integrated into the analytical framework and is treated rather ephemerally. Yet, the role these parties play in coalition games differs from country to country and from time to time, dissolving the image of EU-CEE as a relatively coherent region. Extreme cases are Estonia, where this kind of party is extremely marginal, and Bulgaria as well as Romania, where communist successor parties remain the largest political parties to date, often participating as senior partners in various coalition cabinets. By contrast, in Hungary, the reformed and renamed communist party, which was one of the two dominant parties until 2010, has since then experienced a dramatic decline.

In the same vein, the borrowed-from-the-West framework is blind to coalition dynamics that are brought about by another factor: small ethnic parties. In some countries they play a disproportionate role in coalition games, being able to cooperate with any of the main parties. This is or was regularly the case, for example, with the party of the Turkish minority in Bulgaria, the Hungarian Democratic Union in Romania and the Polish Electoral Action in Lithuania, which is often allied with the Lithuanian Russian Union, as well as with the Party of the Hungarian Coalition in Slovakia. If countries like Croatia or North Macedonia had been included in the research project, the enormous importance of ethnic parties for coalition politics in parts of CEE would have been even more obvious.

To do justice to the editors, it must be acknowledged that they briefly deal with the question of whether CEE is a unified macro-region at the end of the book (pp. 568-569). They seem to be sympathetic to the distinction into three subregions: the Baltic republics, "classical" Central Europe (Poland, the Czech Republic, Slovakia, Hungary, and Slovenia), and the Balkans. This distinction is grounded in different historical trends of longue durée, which have been obscured during the communist era and became partially blurred by the post-1990 developments. However, whatever this argument might elucidate, it is not connected with the empirical research presented in the volume.

All in all, the book provides rich empirical data, which can easily be used for statistical research, being also published open access at the European Representative Democracy Data Archive (www.erdda.org). However, for small-N comparative research, the country chapters might be more valuable as starting points in the search of intricate and fruitful research questions and theoretical insight. These may well be found somewhere beyond the established theoretical framework, which on its part probably needs some adaptation to the conditions of parliamentary democracies in the 21 st century, whether in Eastern Central or in Western Europe.

Funding Open Access funding provided by Projekt DEAL.

Open Access This article is licensed under a Creative Commons Attribution 4.0 International License, which permits use, sharing, adaptation, distribution and reproduction in any medium or format, as long as you give appropriate credit to the original author(s) and the source, provide a link to the Creative Commons licence, and indicate if changes were made. The images or other third party material in this article are included in the article's Creative Commons licence, unless indicated otherwise in a credit line to the material. If material is not included in the article's Creative Commons licence and your intended use is not permitted by statutory regulation or exceeds the permitted use, you will need to obtain permission directly from the copyright holder. To view a copy of this licence, visit http://creativecommons.org/licenses/by/4. $0 /$. 